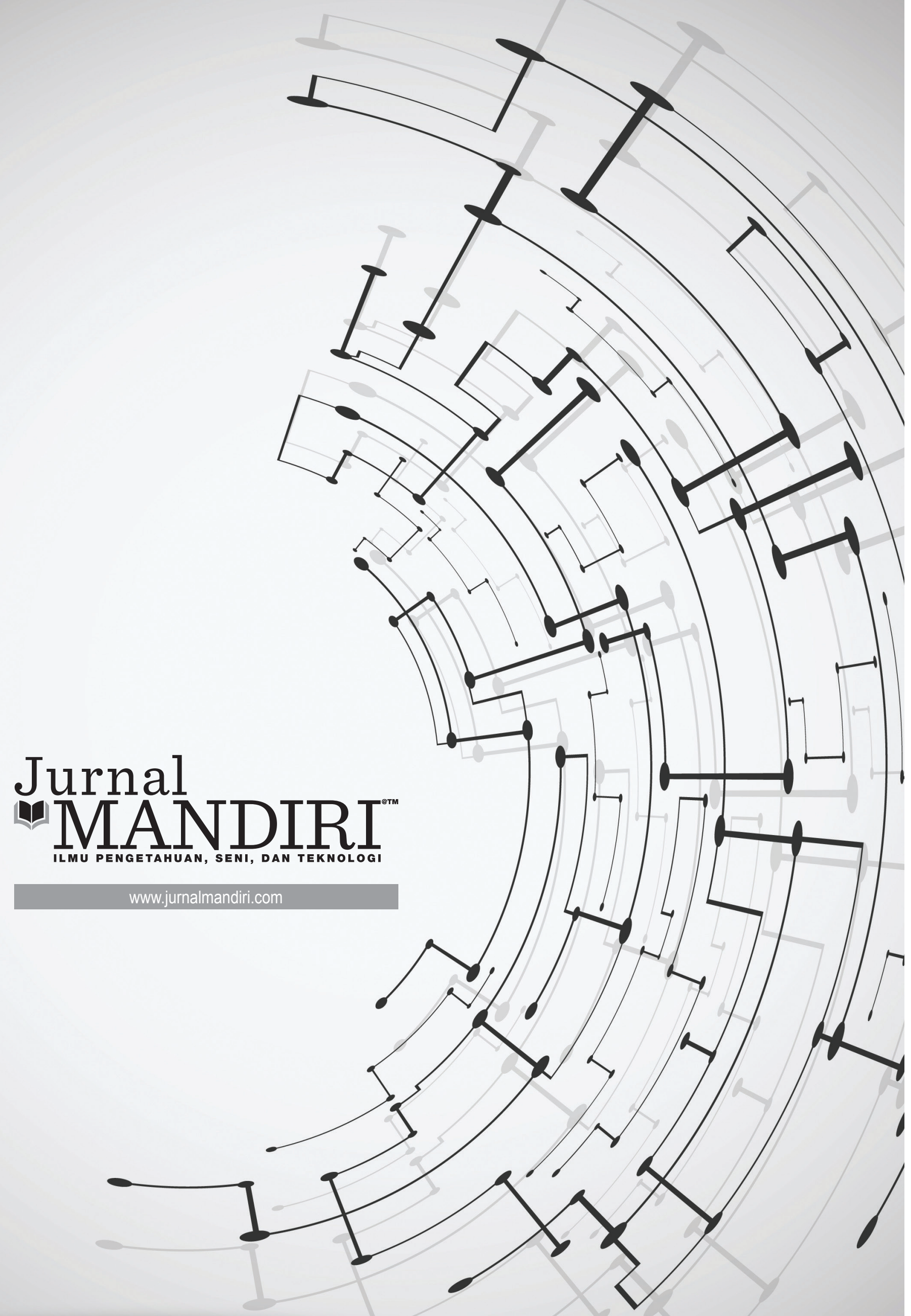


ISSN : 2580-3220, E-ISSN : 2580-4588

J. Mandiri., Vol. 1, No. 2, Desember 2017 (354 - 374)

C2017 Lembaga Kajian Demokrasi

dan Pemberdayaan Masyarakat (LKD-PM)

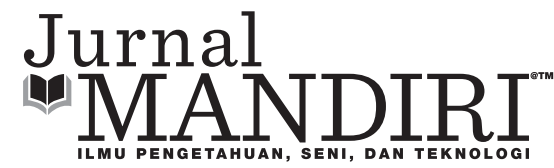

\title{
PENGARUH KEADILAN PROSEDURAL YANG DITERAPKAN KEPEMIMPINAN PEGAWAI DAN KEPUASAN KERJA PEGAWAI TERHADAP KINERJA DARI PEGAWAI BPBD PROVINSI RIAU
}

\author{
Zackharia Rialmi \\ Fakultas Ekonomi Universitas Pamulang \\ zac_rialmi@yahoo.com
}

\begin{abstract}
ABSTRAK
Tujuan Penelitian ini adalah : Untuk menganalisis seberapa besar pengaruh Keadilan Prosedural terhadap Kinerja Pegawai BPBD Provinsi Riau ?, Untuk menganalisis seberapa besar pengaruh Keadilan Prosedural terhadap Kinerja Pegawai melalui Kepuasan Kerja Pegawai BPBD Provinsi Riau ?, Untuk menganalisis seberapa besar pengaruh Kepemimpinan terhadap Kinerja Pegawai BPBD Provinsi Riau?, Untuk menganalisis seberapa besar pengaruh Kepemimpinan terhadap Kinerja melalui Kepuasan Kerja Pegawai BPBD Provinsi Riau ?.Untuk menganalisis seberapa besar pengaruh Keadilan Prosedural dan Kepemimpinan terhadap Kinerja melalui Kepuasan Kerja Pegawai BPBD Provinsi Riau?

Lokasi Penelitian akan dilakukan di Badan Penanggulangan Bencana Daerah Provinsi Riau, Jl.. Jend. Sudirman No. 438, Pekanbaru - Riau. Populasi dan sampel dalam penelitian ini adalah seluruh PNS (Pegawai Negeri Sipil) yang terdapat pada BPBD Provinsi Riau. Populasi dalam penelitian ini relatif kecil yaitu 32 orang (Per November 2012), maka seluruh populasi diambil sebagai responden penelitian ini. Dengan demikian penelitian ini menggunakan metode sensus.

Faktor Keadilan Prosedural, dalam penelitian ini terbukti memberikan kontribusi yang sangat signifikan dalam membangun Kinerja Pegawai pada Badan Penanggulangan Bencana Daerah Provinsi Riau di Kota Pekanbaru sebesar 69,9\%, sedangkan sisanya 30,1\% yang bisa saja dihubungkan oleh faktorfaktor lain yang tidak dimasukan kedalam model ini.

Faktor Kepemimpinan, dalam penelitian ini terbukti memberikan kontribusi yang sangat signifikan dalam membangun Kinerja Pegawai pada Badan Penanggulangan Bencana Daerah Provinsi Riau di Kota Pekanbaru sebesar 69\%, sedangkan sisanya $31 \%$ yang bisa saja dipengaruhi oleh faktor-faktor lain yang tidak dimasukan kedalam model ini.

Faktor Keadilan Prosedural, dalam penelitian ini terbukti kepemimpinan melalui kepuasan kerja memberikan kontribusi yang sangat signifikan dalam membangun Kinerja Pegawai pada Badan Penanggulangan Bencana Daerah Provinsi Riau di Kota Pekanbaru sebesar 64,4\%, sedangkan sisanya 36,6\% yang bisa saja dipengaruhi oleh faktor-faktor lain yang tidak dimasukan ke dalam model ini.
\end{abstract}


Faktor Kepemimpinan dalam penelitian ini terbukti berhubungan dengan Keadilan Prosedural sebesar $62,2 \%$, sedangkan sisanya $37,8 \%$ yang bisa saja dihubungani oleh faktor-faktor lain yang tidak dimasukan kedalam model ini. Faktor Keadilan Prosedural berhubungan terhadap Kepemimpinan yang artinya bahwa Keadilan Prosedural dan Kepemimpinan merupakan faktor yang menjadi penting dalam meningkatkan Kinerja yang ada di badan penanggulangan bencana daerah provinsi riau di kota pekanbaru.

Kata kunci : Keadilan Prosedural, Kepemimpinan, Kepuasan Kerja, Kinerja dan Pegawai

\section{LATAR BELAKANG MASALAH}

Provinsi Riau merupakan salah satu provinsi dengan perkembangan pembangunan yang sangat pesat. Didukung oleh sumberdaya alam yang cukup melimpah seperti, hutan, Migas, pertambangan serta perkebunan, tidak mengherankan jika Provinsi ini dianggap sebagai salah satu Provinsi terkaya di Indonesia. Dibalik kemakmuran yang ditawarkan oleh kekayaan alam, ternyata menyimpan bahaya yang sewaktu-waktu dapat memicu terjadinya bencana. Pembukaan lahan dengan cara membakar contohnya akan menimbulkan bencana asap tidak hanya di Provinsi Riau, tetapi juga berdampak kepada Provinsi yang lain terutama pada Negara-negara tetangga.

Di Bagian Barat Provinsi Riau yang merupakan daerah dengan topografi bergelombang dan di dataran rendah terdapat lahan rawa yang terpotong atau dilalui oleh sungai-sungai yang banyak tertutama sungai besar seperti Sungai Siak, Sungai Rokan dan Sungai Indragiri, kondisi alam demikian tentunya akan memberikan ancaman bencana berupa banjir. Dengan adanya perubahan iklim global saat ini dengan curah hujan yang suatu saat tinggi akan menambah ancaman banjir di Propinsi Riau, dan pada kenyataanya hampir di seluruh wilayah Propinsi Riau setiap tahun mengalami bencana banjir.

Menilik dari banyaknya permasalahan khususnya potensi kerawanan bencana dan kompleksitas dari permasalahan bencana itu sendiri, maka diperlukan SDM (Sumber Daya Manusia) yang berdaya saing tinggi untuk men- dukung kinerja BPBD (Badan Penanggulangan Bencana Daerah) Provinsi Riau sebagai Institusi Resmi Pemerintah yang bergerak didalam penanggulangan Bencana sebagai mana yang telah dipersyaratkan oleh BNPB (Badan Nasional Penanggulangan Bencana).

Undang-undang Nomor 24 Tahun 2007 tentang Penanggulangan Bencana, pada pasal 35 dan pasal 36 mengamanatkan setiap daerah harus mempunyai perencanaan penanggulangan bencana. Secara rinci hal tersebut dijelaskan dalam ketentuan Pasal 6 ayat (5) Peraturan Pemerintah Nomor 21 Tahun 2008 tentang Penyelenggaraan Penanggulangan Bencana. RPB (Risiko Penanggulangan Bencana) Provinsi Riau ditetapkan oleh Pemerintah Provinsi Riau sesuai dengan kewenangannya untuk jangka waktu 5 (lima) tahun. Selanjutnya dalam Pasal 2, Pasal 3 dan Pasal 4 Peraturan Daerah Provinsi Riau No. 2 tahun 2010 tentang pembentukan, kedudukan dan tugas pokok Badan Penanggulangan Bencana Daerah (BPBD) dan Pasal 2, Pasal 3 dan Pasal 4 Peraturan Gubernur Riau No.16 Tahun 2011 tentang susunan organisasi, uraian tugas dan fungsi Badan Penanggulangan Bencana Daerah Provinsi Riau, disimpulkan bahwa Pemerintah Provinsi Riau perlu merumuskan dan menetapkan Rencana Penanggulangan Bencana Provinsi Riau Tahun 2012-2017, yang mampu menjadi pedoman dalam pelaksanaan praktik-praktik penanggulangan bencana di Provinsi Riau yang terbagi dalam setiap wilayah Kabupaten dan Kota baik pada masa sebelum, saat, maupun sesudah terjadinya bencana. 
Beberapa tokoh teori Manusia juga lebih menyukai istilah Human Capital karena menurut mereka seorang Pegawai merupakan kombinasi dari 3 (tiga) jenis modal yang dibutuhkan oleh Organisasi, yaitu: Social Capital, Knowledge Capital, dan Personel Capital. Ketiga jenis modal ini jelas mempunyai nilai tambah yang sangat penting bagi semua Organisasi. Setiap Pegawai merupakan perwujudan dari ketiga modal ini dan memainkan peran unik yang tidak bisa digantikan oleh faktor produksi dan pelayanan yang lain, Oleh karena itu, sebuah organisasi dengan banyak human capital-nya yang "hebat" akan mengalahkan organisasi yang human capital-nya yang "tidak hebat".

Seberapa besar sumbangsih positif maupun negatif yang ditunjukan oleh masing-masing Pegawai kepada Organisasi sangat tergantung pada kinerja yang dapat diberikan dan ditunjukan oleh Pegawai selama bekerja. Berbicara mengenai kinerja Pegawai maka tidak akan terlepas dengan kondisi apa yang dialami dan didapatkan oleh Pegawai selama bekerja, baik itu kondisi yang adil maupun komitmen yang ada pada dirinya untuk memajukan organisasi tempat mereka bekerja.

Dalam perkembangannya BPBD Provinsi Riau masih sering sekali diragukan kapabilitas dan kemampuannya untuk melakukan penanggulangan bencana dengan baik. Nada sumbang dan keraguan publik atas BPBD Provinsi Riau memang dapat dimaklumi, selain karena usianya yang masih baru (didirikan tahun 2010), BPBD juga berbeda dengan BNPB yang melakukan perekrutan berdasarkan spesifikasi keilmuan yang dibutuhkan, BPBD Provinsi Riau masih diisi oleh Pegawai yang diambil dari SKPD-SKPD yang ada, bahkan ada yang merasa diri sebagai "Pegawai Buangan" ketika dipindahkan dari SKPD sebelumnya.

Berdasarkam uraian singkat diatas, penulis tertarik untuk meneliti dan membahas mengenai pengaruh keadilan prosedural yang diterapkan Kepemimpinan pegawai dan Kepuasan Kerja pegawai terhadap kinerja dari Pegawai BPBD Provinsi Riau.

\section{PERUMUSAN MASALAH}

Berdasarkan uraian latar belakang di atas, maka perumusan masalah dalam penelitian ini adalah:

1. Bagaimana pengaruh Keadilan Prosedural terhadap Kinerja Pegawai BPBD Provinsi Riau?

2. Bagaimana pengaruh Keadilan Prosedural terhadap Kinerja Pegawai melalui Kepuasan Kerja Pegawai BPBD Provinsi Riau?

3. Bagaimana pengaruh Kepemimpinan terhadap Kinerja Pegawai BPBD Provinsi Riau?

4. Bagaimana pengaruh Kepemimpinan terhadap Kinerja melalui Kepuasan Kerja Pegawai BPBD Provinsi Riau?

5. Bagaimana pengaruh Keadilan Prosedural dan Kepemimpinan terhadap Kinerja melalui Kepuasan Kerja Pegawai BPBD Provinsi Riau?

\section{TUJUAN PENELITIAN INI ADALAH}

1. Untuk menganalisis seberapa besar pengaruh Keadilan Prosedural terhadap Kinerja Pegawai BPBD Provinsi Riau?

2. Untuk menganalisis seberapa besar pengaruh Keadilan Prosedural terhadap Kinerja Pegawai melalui Kepuasan Kerja Pegawai BPBD Provinsi Riau?

3. Untuk menganalisis seberapa besar pengaruh Kepemimpinan terhadap Kinerja Pegawai BPBD Provinsi Riau?

4. Untuk menganalisis seberapa besar pengaruh Kepemimpinan terhadap Kinerja melalui Kepuasan Kerja Pegawai BPBD Provinsi Riau?

5. Untuk menganalisis seberapa besar pengaruh Keadilan Prosedural dan Kepemimpinan terhadap Kinerja melalui Kepuasan Kerja Pegawai BPBD Provinsi Riau?

\section{KAJIAN TEORI KINERJA}

Kinerja (performance) adalah hasil kerja yang dapat dicapai oleh seorang atau sekelompok orang dalam suatu organisasi, sesuai 
dengan wewenang dan tanggungjawab masing-masing dalam rangka usaha mencapai tujuan organisasi bersangkutan secara legal, tidak melanggar hukum dan sesuai dengan moral dan etika (Suyadi Prawirosentono, 2008:2).

Menurut Bastian (2006:274) kinerja adalah gambaran pencapaian pelaksanaan suatu kegiatan/program/kebijaksanaan dalam mewujudkan sasaran, tujuan, misi, dan visi organisasi.

Pengukuran kinerja menurut Mulyadi (2007:359) adalah penentuan secara periodik efektivitas operasional suatu organisasi, bagian organisasi, dan personilnya, berdasarkan sasaran strategik, standar, dan kriteria yang telah ditetapkan sebelumnya.

Dari beberapa pengertian diatas, dapat disimpulkan bahwa kinerja adalah kemampuan Pekerja sebagai bagian dari organisasi atau perusahaan untuk menterjemahkan dan mencapai tujuan Perusahaan sesuai dengan kemampuan dan tanggung jawab yang dipercayakan kepadanya.

Tujuan Penilaian Kinerja :

1. Untuk memotivasi personal dalam mencapai sasaran organisasi dan dalam mematuhi standar perilaku yang ditetapkan sebelumnya, agar membuahkan tindakan dan hasil yang diinginkan organisasi dalam sisi ini kinerja dapat mendorong kemampuan personal untuk mengembangkan diri, tetapi organisasi juga harus mengontrol personal masing-masing karyawan". (Mulyadi $2000: 420$ ).

2. Untuk menekan perilaku yang tidak semestinya dan untuk merangsang serta menegakkan prilaku yang semestinya diinginkan, melalui umpan balik hasil kinerja pada waktunya serta pemberian penghargaan, baik yang bersifat instrinsik dan ekstrinsik (Mulyadi $2000: 422$ ).

3. Sebagai alat perencanaan dan pengendalian organisasi atau badan usaha untuk membantu proses pengambilan keputusan dalam organisasi atau badan usaha yang pada akhirnya akan memberikan dasar yang baik bagi pihak manajemen organisasi atau badan usaha secara keseluruhan (Dikutip dari skripsi Universitas Kristen PETRA, 2010).

\section{FAKTOR YANGMEMPENGARUHI KINERJA}

Kinerja merupakan suatu konstruk multidimensional yang mencakup banyak faktor yang mempengaruhinya. Faktor-faktor tersebut antara lain :

1. Faktor personal/individu yang meliputi pengetahuan, ketrampilan (skill), kemampuan, kepercayaan diri, motivasi dan komitmen yang dimiliki oleh setiap individu.

2. Faktor kepemimpinan yang meliputi kualitas dalam memberikan dorongan, semangat, arahan dan dukungan yang diberikan manager dan team leader.

3. Faktor tim yang meliputi kualitas dukungan dan semangat yang diberikan oleh rekan dalam satu kepercayaan terhadap sesama anggota tim, kekompakan dan keeratan anggota tim.

4. Faktor sistem yang meliputi: sistem kerja, fasilitas kerja atau infrastruktur yang diberikan oleh organisasi, proses organisasi dan kultur kinerja dalam organisasi.

5. Faktor kontekstual (situasional) yang meliputi tekanan dan perubahan lingkungan eksternal dan internal.

\section{KEADILAN PROSEDURAL}

Keadilan pada hakikatnya adalah memperlakukan seseorang atau pihak lain sesuai dengan haknya. Keadilan berasal dari kata adil. Menurut W.J.S Poerwodarminto kata adil berarti tidak berat sebelah, sepatuttnya, tidak sewenang-wenang dan tidak memihak. Teori mengenai keadilan menganggap bahwa individu membandingkan antara masukan dan keluaran pekerjaan mereka dengan masukan atau keluaran orang lain dan kemudian berespon untuk menghapuskan setiap ketidakadilan (Ikhsan A dan Iskhak M, 2005 : 16). 
Bierhoff dalam Kaddarudin (2006:7) menyatakan bahwa perdebatan mengenai teori mengenai keadilan organisasional pada mulanya lebih menekankan pada aspek keadilan distributif, namun pada akhir-akhir ini perspektif Keadilan Prosedural semakin banyak mendapatkan perhatian peneliti.

McFarlin dan Sweeney dalam Harris (2000:2) yang menyatakan bahwa penelitian mengenai keadilan organisasional menyatakan bahwa keadilan distributif memiliki hubungan terhadap perasaan keadilan terhadap hasil akhir, yang memhubungani kinerja juga, meskipun lebih rendah daripada Keadilan Prosedural. Penelitian lain menunjukkan bahwa individu akan menampilkan tingkat kinerja dan tingkat komitmen yang lebih tinggi, peningkatan kerja dan kepuasan pembayaran, peningkatan tingkat kepercayaan, dan sikap anggota organisasi ketika mereka merasa bahwa proses pengambilan keputusan adil, dan mereka diperlakukan dengan adil (Rupp dan Cropanzano dalam Byrne et al., 2003).

Berdasarkan teori keadilan, bila Pegawai mempersepsikan suatu ketidakadilan mereka dapat meramalkan untuk mengambil salah satu dari enam pilihan yaitu mengubah masukan, mengubah keluaran, mendistorsikan persepsi mengenai diri, mendistorsikan persepsi mengenai orang lain, memilih acuan yang berlainan dan meninggalkan medan (Robbin, 2003:24).

Menurut Greenberg (1996:8) keadilan distributif dan Keadilan Prosedural menekankan aspek formal keadilan dan masih menurut Greenberg, aspek informal keadilan merupakan fenomena yang tidak kalah penting.

Dari beberapa definisi diatas dapat disimpulkan bahwa berbicara mengenai keadilan maupun ketidakadilan akan selalu berkaitan dengan keadilan distributive, meskipun lebih rendah daripada Keadilan Prosedural tetapi memiliki hubungan terhadap perasaan keadilan terhadap hasil akhir, yang juga berhubungan terhadap kinerja.
INDIKATOR KEADILAN PROSEDURAL

Keadilan Prosedural berhubungan dengan:

a. Persepsi bawahan akan suatu bentuk keadilan dari semua proses yang diterapkan oleh pihak atasan dalam Institusi tersebut dan untuk mengevaluasi kinerja Pegawai.

b. Mengkomunikasikan umpan balik kinerja dan menentukan apakah penghargaan yang mereka terima seperti promosi atau kenaikan jabatan dan peningkatan gaji (Mc. Farlin dan Sweeny, 1992).

c. Keadilan Prosedural yang bernilai tinggi atau rendah akan terjadi saat pihak bawahan merasakan bahwa prosedur dalam Institusi dan proses yang terjadi dalam Institusi adalah adil atau tidak adil.

d. Keadilan Prosedural dimulai dengan hipotesis yang menyatakan adanya kelompok reaksi psikologis atas suatu kepatuhan atau pelanggaran terhadap norma yang menjelaskan pada perlakuan tertentu atau dalam pola lokasi tertentu. Norma yang membentuk suatu dasar dari respon keadilan dapat dibagi menjadi dua kategori yaitu kategori yang berhubungan dengan hasil akhir sosial (keadilan distributif) dan kategori yang berhubungan dnegan proses sosial (Keadilan Prosedural) yaitu perilaku yang tepat dan perlakuan terhadap individu.

Leventhal (1980) dalam Lau dan Eggleton (2008) mengidentifikasi empat kriteria yang dapat memhubungani persepsi akan sebuah keadilan yaitu :

a. konsistensi atau kesesuaian, yang artinya adalah prosedur yang ada harus diterapkan secara konsisten antar individu dan terjadi sepanjang waktu

b. penekanan terhadap bias, yang artinya adalah pengambil keputusan tidak boleh memiliki kepentingan pribadi

c. akurasi informasi yang menjadi dasar suatu keputusan dan

d. kesepakatan terhadap standar etika personal dan moralitas.

Dari berbagai pandangan ahli mengenai 
indicator keadilan Prosedural, Penulis menyimpulkan bahwa keadilan procedural berbicara mengenai : Sifat aturan formal, Penjelasan terhadap prosedur dan pengambilan keputusan, serta Perlakuan Interpersonal.

\section{KEPEMIMPINAN}

Stoner (dalam T. Hani Handoko, 2003:26), kepemimpinan manajerial dapat didefinisikan sebagai suatu proses pengarahan dan pemberian hubungan pada kegiatan-kegiatan dari sekelompok anggota yang saling berhubungan tugasnya. Implikasi dari definisi tersebut adalah :

1. Kepemimpinan menyangkut orang lain bawahan atau pengikut. Kesedian mereka untuk menerima pengarahan dari pemimpin, para anggota kelompok membantu menentukan status/kedudukan pemimpin dan membuat proses kepemimpinan dapat berjalan. Tanpa bawahan, semua kualitas kepemimpinan seorang manajer akan menjadi tidak relevan.

2. Kepemimpinan menyangkut suatu pembagian kekuasaan yang tidak seimbang di antara para pemimpin dan anggota kelompok. Para pemimpin mempunyai wewenang untuk mengarahkan berbagai kegiatan para anggota kelompok, tetapi para anggota kelompk tidak dapat mengarahkan kegiatan-kegiatan pemimpin secara langsung, meskipun dapat juga melalui sejumlah cara secara tidak langsung.

3. Selain dapat memberikan pengarahan kepada para bawahan atau pengikut, pemimpin daat juga mempergunakan hubungan. Dengan kata lain, para pemimpin tidak hanya dapat memerintah bawahan apa yang harus dilakukan tetapi juga daat memhubungani bagaimana bawahan melaksanakan perintahnya.

Penelitian-penelitian dan teori-teori kepemimpinan dapat diklasifisikan sebagai pendekatan-pendekatan kesifatan, perilaku, dan situasional (kontijensi) dalam studi tentang kepemimpinan.
Pendekatan pertama memandang kepemimpinan sebagai suatu kombinasi sifat-sifat (traits) yang tampak. Pendekatan kedua bermaksud mengidentifikasikan perilaku-perilaku (behaviors) pribadi yang berhubungan dengan kepemimpinan efektif. Kedua pendekatan ini mempunyai anggapan bahwa seorang individu yang memiliki sifat-sifat tertentu atau memperagakan perilaku-perilaku tertentu akan muncul sebagai pemimpin dalam situasi kelompok apapun dimana dia berada.

Pemikiran dan penelitian sekarang mendasarkan pada pendekatan ketiga, yaitu pandangan situasional tentang kepemimpinan. Pandangan ini menganggap bahwa kondisi yang menentukan efektivitas kepemimpinan bervariasi dengan situasi - tugas-tugas yang dilakukan, keterampilan, dan pengaharapan bawahan, lingkungan organisasi, pengalaman masa lalu pemimpin dan bawahan, dan sebagainya. Pandangan ini telah menimbulkan pendekatan "contigency" pada kepemimpinan, yang bermaksud untuk menetapkan faktorfaktor situasional yang menentukan seberapa brsar efektifitas situasi gaya kepemimpinan tertentu.

\section{INDIKATOR KEPEMIMPINAN}

Edwin Ghiselli (dalam T. Hani Handoko, 2003) dalam penelitiannya telah menunjukan sifat-sifat tertentu yang tampaknya penting untuk kepemimpinan efektif. Sifat-sifat tersebut adalah sbb :

1. Kemampuan dalam kedudukannya sebagai pengawas (Supervisory Ability) atau pelaksanaan fungsi-fungsi dasar manajemen, terutama pengarahan dan pengawasan pekerjaan orang lain.

2. Kebutuhan akan prestasi dalam pekerjaan, mencakup pencarian tanggung jawab dan keinginan sukses.

3. Kecerdasan, mencakup kebijakan, pemikiran kreatif dan daya pikir.

4. Ketegasan (decisiveness), atau kemampuan untuk membuat keputusan-keputusan dan 
memecahkan masalah-masalah dengan cakap dan tepat.

5. Kepercayaan diri, atau pandangan terhadap dirinya sebagai kemampuan untuk menghadapi masalah.

6. Inisiatif, atau kemampuan untuk bertindak tidak tergantung, mengembangkan serangkaian kegiatan dan menemukan cara-cara baru atau inovasi.

Keith Davis mengiktisarkan 4 (empat) ciri/ sifat utama yang mempunyai hubungan terhadap kesuksesan kepemimpinan organisasi:

1. Kecerdasan

2. Kedewasaan dan keluasan hubungan sosial

3. Motivasi diri dan dorongan berprestasi dan

4. Sikap-sikap hubungan manusiawi.

Pendekatan perilaku memusatkan perhatiannya pada dua aspek perilaku kepemimpinan, yaitu fungsi-fungsi dan gaya-gaya kepemimpinan. Peneliti mengambil pandangan dari Edwin Ghiselli (dalam T. Hani Handoko, 2003) dalam penelitiannya telah menunjukan sifatsifat tertentu yang tampaknya penting untuk kepemimpinan efektif, yang dirasa paling cocok digunakan dalam penelitian ini.

\section{GAYA-GAYA KEPEMIMPINAN}

Pandangan kedua tentang perilaku kepemimpinan memusatkan pada gaya pemimpin dalam hubungannya dengan bawahan. Para peneliti telah mengidentifikasikan dua gaya kepemimpinan : gaya dengan orientasi tugas (task oriented) dan gaya dengan orientasi karyawan (employee-oriented). Manajer berorientasi tugas mengarahkan dan mengawasi bawahan secara tertutup untuk menjamin bahwa tugas dilaksanakan sesuai yang diinginkannya. Manajer dengan gaya kepemimpinan ini lebih memperhatikan pelaksanaan pekerjaan daripada pengembangan dan pertumbuhan karyawan. Manajer berorientasi karyawan mencoba untuk lebih memotivasi bawahan dibanding mengawasi mereka. Mereka mendorong para anggota kelompok untuk melaksanakan tugas-tugas dengan memberikan kesempatan bawahan untuk berpartisipasi dalam pembuatan keputusan, menciptakan suasana persahabatan serta hubungan-hubungan saling mempercayai dan menghormati dengan para anggota kelompok.

Corak atau gaya kepemimpinan (leadership style) seorang manajer akan sangat berhubungan terhadap efektifitas pemimpin. Gaya kepemimpinan ada delapan, yaitu tipe kharismatis, paternalistis, militeristis, otokratis, laissez faire, populistis, administratif dan tipe demokratis (Kartono, 2003).

\section{KEPUASAN KERJA}

Menurut Davis dan Newton (1996) menyatakan bahwa Kepuasan Kerja sebagai seperangkat peraturan yang menyangkut tentang perasaan menyenangkan dan tidak menyenangkan berhubungan dengan pekerjaan mereka, pegawai yang bergabung dalam suatu organisasi akan membawa keinginan, kebutuhan, hasrat dan pengalaman masa lalu yang membentuk harapan kerja sehingga Kepuasan Kerja menunjukkan kesesuaian antara harapan seseorang yang timbul berkaitan dengan pekerjaan yang disediakan sebagai sekumpulan perasaan, Kepuasan Kerja yang bersifat dinamik (Meyer dan Tett, 1993).

Selanjutnya Ostroff (1992) mengemukakan bahwa Kepuasan Kerja Pegawai dan kondisi kerja yang baik mempunyai hubungan kerja yang signifikan dengan kinerja, selanjutnya Pegawai yang merasa puas dengan pekerjaannya biasanya mereka bekerja lebih keras dan lebih baik disbanding dengan Pegawai yang mengalami stress yang disebabkan dengan kondisi kerja yang tidak kondusif. Kepuasan Kerja dan sikap Pegawai merupakan suatu hal yang penting dalam menentukan perilaku dan respon terhadap pekerjaan dan melalui perilaku tersebut organisasi yang efektif dapat tercapai.

\section{INDIKATOR KEPUASAN KERJA}

De Vries (1978) dalam Mas'ud (2004) merumuskan indikator-indikator Kepuasan Kerja dalam 5 (lima) indikator-indikator Kepuasan 
Kerja dalam 5 (lima) indikator sebagai berikut:

1. Kepuasan dengan gaji

2. Kepuasan dengan promosi

3. Kepuasan dengan rekan kerja

4. Kepuasan dengan penyelia

5. Kepuasan dengan pekerjaan itu sendiri Hubungan antara bawahan dengan pihak pimpinan sangat penting artinya dalam meningkatkan produktivitas kerja. Kepuasan Kerja dapat ditingkatkan melalui perhatian dan hubungan baik dari pimpinan kepada bawahan, sehingga Pegawai akan merasa bahwa dirinya merupakan bagian yang penting dari organisasi kerja.

Kepemimpinan didasarkan pada perilaku yang terutama berasal dari ketidakleluasaan menggunakan keterampilan pekerja sehingga meninggalkan organisasi yang mengikatnya. Saat komitmen dicontohkan sebagai fungsi kepercayaan terhadap organisasi dan pengalaman kerja, karakteristik organisasi harusnya menjadi faktor yang memhubungani kepercayaan pekerja terhadap organisasi dan oleh karena itu pada level komitmen pekerja; karakteristik kerja harusnya menjadi faktor utama yang memhubungani pengalaman kerja dan Kepuasan Kerja dari pekerja. Variabel komitmen dalam penelitian ini diukur melalui kepercayaan yang kuat terhadap tujuan dan nilai organisasi, kemauan besar untuk berusaha bagi organisasi dan hasrat yang kuat untuk tetap menjadi anggota organisasi tersebut.

Indikator inilah yang digunakan oleh peneliti untuk mengukur kepuasan kerja Pekerja di Badan Penanggulangan Bencana Daerah Provinsi Riau

\section{METODELOGI PENELITIAN}

\section{Lokasi Penelitian}

Lokasi Penelitian akan dilakukan di Badan Penanggulangan Bencana Daerah Provinsi Riau, Jl.. Jend. Sudirman No. 438, Pekanbaru - Riau.

\section{Populasi dan Sampel}

Populasi didefinisikan sebagai totalitas unit analisis yang sedang diteliti atau keseluruhan unit analisis. Sedangkan sampel merupakan bagian dari populasi atau atau bagian yang dipilih secara sengaja atau tidak, dari populasi yang dianggap mewakili populasi. (Wijaya, 2011:6). Populasi dan sampel dalam penelitian ini adalah seluruh PNS (Pegawai Negeri Sipil) yang terdapat pada BPBD Provinsi Riau. Populasi dalam penelitian ini relatif kecil yaitu 32 orang (Per November 2012), maka seluruh populasi diambil sebagai responden penelitian ini. Dengan demikian penelitian ini menggunakan metode sensus.

\section{Jenis dan Sumber Data}

Jenis data dapat dibagi menjadi dua yaitu data primer dan data sekunder. Data primer adalah data yang diambil dari sumber asli tanpa ada perantaranya.Sedangkan data sekunder adalah data yang didapat melalui media perantara seperti data dokumenter. Jenis data yang digunakan dalam penelitian ini adalah data primer. Sumber penelitian yaitu dengan cara penyebaran kuesioner kepada responden.

\section{TEKNIK PENGUMPULAN DATA}

Dalam penelitian ini yang akan diberikan kuesioner adalah seluruh PNS (Pegawai Negeri Sipil) yang terdapat pada BPBD Provinsi Riau sesuai dengan kriteria pemilihan sampel. Tahapan dalam pengumpulan terdiri dari dua tahap, yaitu : melakukan penyebaran kuesioner kepada seluruh PNS (Pegawai Negeri Sipil) yang terdapat pada BPBD Provinsi Riau melalui Humas BPBD Provinsi Riau. Tahapan yang kedua adalah pengambilan kuesioner yang telah diisi oleh (Pegawai Negeri Sipil) yang terdapat pada BPBD Provinsi Riau. Teknik kuesioner yaitu teknik pengumpulan data yang dilakukan dengan cara memberi seperangkat pertanyaan dan pernyataan secara tertulis kepada responden untuk dijawabnya (Sugiyono, 2008).

\section{DESAIN PENELITIAN}

Berdasarkan variabel-variabel yang telah dijelaskan dalam hipotesis, maka dibutuhkan 
analisis data dengan menggunakan pengujian regresi berganda (multiple regresion). Dalam analisis regresi, selain mengukur kekuatan hubungan antara dua variabel, juga menunjukan arah hubungan antara variabel dependen dengan variabel independen (Riduwan, 2007). Persamaan regresinya adalah sbb:

1. Hipotesis 1 (Hubungan $\mathrm{X} 1$ ke Y2)

$$
\begin{aligned}
& \mathrm{Y} 2=P 31 \mathrm{X} 1+\mathrm{e} \\
& \mathrm{Y} 2=0,335 \mathrm{X} 1+\mathrm{e}
\end{aligned}
$$

2. Hipotesis 2 (Hubungan X1 ke Y2 melalui Y1)

$$
\begin{aligned}
& \mathrm{Y} 2=P 21 \mathrm{X} 1+P 4 \mathrm{Y} 1+\mathrm{e} \\
& \mathrm{Y} 2=0,368 \mathrm{X} 1+0,234 \mathrm{Y} 1+\mathrm{e}
\end{aligned}
$$

3. Hipotesis 3 (Hubungan $\mathrm{X} 2$ ke $\mathrm{Y} 2$ )

$$
\begin{aligned}
& \mathrm{Y} 2=P 32 \mathrm{X} 2+\mathrm{e} \\
& \mathrm{Y} 2=0,551 \mathrm{X} 2+\mathrm{e}
\end{aligned}
$$

4. Hipotesis 4 (Hubungan X2 ke Y2 melalui Y1)

$$
\begin{aligned}
& \mathrm{Y} 2=P 22 \mathrm{X} 2+P 4 \mathrm{Y} 1+\mathrm{e} \\
& \mathrm{Y} 2=0,492 \mathrm{X} 2+0,234 \mathrm{Y} 1+\mathrm{e}
\end{aligned}
$$

5. Hipotesis 5 (Hubungan X1, X2 ke Y2 melalui Y1)

$$
\begin{aligned}
& \mathrm{Y} 2=P 21 \mathrm{X} 1+P 4 \mathrm{Y} 1+\mathrm{e} \\
& \mathrm{Y} 2=P 22 \mathrm{X} 2+P 4 \mathrm{Y} 1+\mathrm{e} \\
& \mathrm{Y} 2=0,368 \mathrm{X} 1+0,234 \mathrm{Y} 1+\mathrm{e}
\end{aligned}
$$$$
\mathrm{Y} 2=0,492 \mathrm{X} 2+0,234 \mathrm{Y} 1+\mathrm{e}
$$

Dimana,

$\mathrm{Y} 1=$ Kepuasan Kerja

$\mathrm{Y} 2$ = Kinerja

$\mathrm{X} 1=$ Keadilan Prosedural

$\mathrm{X} 2$ = Kepemimpinan

$\beta 0=$ Konstanta

$\beta 1,2=$ Koefisien regresi dari masing-masing variabel

e $=$ error term (faktor kesalahan)

\section{VARIABEL PENELITIAN}

\section{Keadilan Prosedural (X1)}

Keadilan Prosedural mutlak diperlukan oleh Pegawai di dalam memainkan perannya. Greenberg (1996) dalam Faturochman (1999) selanjutnya menjelaskan terdapat 3 (tiga) komponen pokok didalam Keadilan Prosedural yakni : (1) Sifat aturan formal dari prosedur yang berlaku, (2) Penjelasan terhadap prosedur dan pengambilan keputusan, (3) Perlakuan Interpersonal.

\section{Kepemimpinan (X2)}

Edwin Ghiselli (Dalam T. Handoko, 2003) mengemukakan 6 (enam), yakni (1) Kemampuan dalam kedudukannya sebagai pengawas (2) Kebutuhan akan prestasi dalam pekerjaan, mencakup pencarian tanggung jawab dan keinginan sukse, (3) Kecerdasan, (4) Ketegasan , (5) Kepercayaan Diri, (6) Inisiatif.

\section{Kepuasan Kerja (Y1)}

Konsep Kepuasan Kerja secara gamblang juga dikemukakan oleh Robbin (1996), dimana Kepuasan Kerja diasumsikan sebagai tingkat kesenangan yang dirasakan atas perananan dan pekerjaan dalam suatu organisasi, sedangkan yang menjadi indikator Kepuasan Kerja adalah : (1) Kepuasan Kerja sebagai respon emosional terhadap situasi kerja (kondisi kerja itu sendiri), (2) hasil kerja yang diperoleh atau yang diharapkan (pendapatan dan promosi), (3) Kepuasan Kerja mempresentasikan beberapa sikap yang merupakan sumber Kepuasan Kerja (hubungan kerja dengan atasan dan rekan kerja).

\section{Kinerja Pegawai (Y2)}

AA. Anwar Prabu Mankunegara (2007) mengemukakaan bahwa kinerja karyawan (prestasi kerja) adalah hasil kerja secara kualitas dan kuantitas yang dicapai oleh seseorang karyawan dalam melaksanakan tugasnya sesuai dengan tanggung jawab yang diberikan kepadanya.

Selanjutnya dikemukakan bahwa aspek standar kinerja meliputi aspek kuantitas dan kualitas. Adapun aspek kuantitatif meliputi : (1) Proses kerja dan kondisi pekerjaan, (2) Waktu yang dipergunakan atau lamanya melaksanakan pekerjaan, (3) Jumlah kesalahan dalam melaksanakan pekerjaan, (4) Jumlah dan jenis pemberian pelayanan dalam bekerja. Sedangkan aspek kualitatif meliputi : (1) Ketepatan kerja dan 
kualitas pekerjaan, (2) Tingkat kemampuan dalam bekerja, (3) Kemampuan menganalisa data/informasi, kemampuan/kegagalan menggunakan mesin/peralatan, (4) Kemampuan mengevaluasi (keluhan/keberatan konsumen).

\section{TEKNIK ANALISA DATA}

Sebelum pengujian dilakukan terhadap penelitian, maka terlebih dahulu akan dilakukan uji kualitas data, yaitu pengujian validitas ( $v a-$ lidity test) dan pengujian reliabilitas (reliability test).

Uji normalitas dilakukan untuk memastikan bahwa masing-masing item dalam instrumen penelitian mampu mengukur variabel yang ditetapkan dalam penelitian ini. Sebuah instrumen dikatakan valid, jika mampu mengukur apa yang diinginkan dan mengungkapkan data variabel yang diteliti secara tepat (Ghozali, 2001: 45).

\section{METODE ANALISIS}

Analisis data digunakan Analisis Regresi
Moderate Two Way Interaction, dengan langkah teknis analisis bertitik tolak dari daya yang dikumpulkan melalui angket. Adapun langkah kerja (1) Tabulasi dan Deskripsi Data, (2) Pengujian persyaratan analisis data, (3) Pengujian Hipotesis Penelitian.

Program SPSS digunakan sebagai alat bantu untuk pembuktian hipotesis yang dijelaskan diatas.

\section{DESKRIPSI HASIL PENELITIAN}

Keadilan Prosedural pada Badan Penanggulangan Bencana Daerah Provinsi Riau di Kota Pekanbaru.

Berdasarkan hasil perhitungan terhadap skor Keadilan Prosedural di Badan Penanggulangan Bencana Daerah Provinsi Riau di Kota Pekanbaru tersebut. Selanjutnya penyebaran distribusi frekuensi data Keadilan Prosedural Badan Penanggulangan Bencana Daerah Provinsi Riau di Kota Pekanbaru dapat dilihat pada tabel 8 berikut :

Tabel 8. Distribusi Frekuensi Skor Keadilan Prosedural Badan Penanggulangan Bencana Daerah Provinsi Riau di Kota Pekanbaru $\left(\mathrm{X}_{1}\right)$

\begin{tabular}{|c|c|c|c|c|c|c|c|c|c|c|c|c|c|c|c|}
\hline \multirow{3}{*}{ Indikator } & \multicolumn{14}{|c|}{ Distribusi Jawaban Rponden } & \multirow{3}{*}{ Rata-rata } \\
\hline & \multicolumn{2}{|c|}{ SSTS } & \multicolumn{2}{|c|}{ STS } & \multicolumn{2}{|c|}{ TS } & \multicolumn{2}{|c|}{$\mathbf{R R}$} & \multicolumn{2}{|c|}{ S } & \multicolumn{2}{|c|}{ SS } & \multicolumn{2}{|c|}{ SSS } & \\
\hline & $f$ & $\%$ & $\mathbf{F}$ & $\%$ & $\mathbf{F}$ & $\%$ & $\mathbf{F}$ & $\%$ & $f$ & $\%$ & $F$ & $\%$ & f & $\%$ & \\
\hline X1.1 & 1 & 3,13 & 2 & 6,25 & 4 & 12,5 & 7 & 21,9 & 10 & 31,3 & 3 & 9,38 & 5 & 15,6 & 4,63 \\
\hline $\mathrm{X} 1.2$ & 1 & 3,13 & 4 & 12,50 & 6 & 18,8 & 3 & 9,38 & 5 & 15,6 & 7 & 21,9 & 6 & 18,8 & 4,63 \\
\hline X1.3 & 0 & 0 & 3 & 9,38 & 7 & 21,9 & 4 & 12,5 & 5 & 15,6 & 10 & 31,3 & 3 & 9,38 & 4,66 \\
\hline X1.4 & 2 & 6,25 & 3 & 9,38 & 10 & 31,3 & 2 & 6,25 & 6 & 18,8 & 6 & 18,8 & 3 & 9,38 & 4,16 \\
\hline X1.5 & 0 & 0 & 1 & 3,13 & 9 & 28,1 & 5 & 15,6 & 7 & 21,9 & 5 & 15,6 & 5 & 15,60 & 4,66 \\
\hline X1.6 & 2 & 6,25 & 5 & 15,60 & 7 & 21,9 & 3 & 9,38 & 6 & 18,8 & 4 & 12,5 & 5 & 15,60 & 4,19 \\
\hline $\mathrm{X} 1.7$ & 0 & 0 & 2 & 6,25 & 6 & 18,8 & 7 & 21,9 & 5 & 15,6 & 4 & 12,5 & 8 & 25,00 & 4,84 \\
\hline X1.8 & 1 & 3,13 & 3 & 9,38 & 6 & 18,8 & 5 & 15,6 & 6 & 18,8 & 8 & 25 & 3 & 9,38 & 4,5 \\
\hline X1.9 & 2 & 6,25 & 1 & 3,13 & 6 & 18,8 & 6 & 18,8 & 7 & 21,9 & 7 & 21,90 & 3 & 9,38 & 4,5 \\
\hline $\mathrm{X} 1.10$ & 2 & 6,25 & 5 & 15,6 & 5 & 15,6 & 5 & 15,6 & 7 & 21,9 & 5 & 15,60 & 3 & 9,38 & 4,16 \\
\hline X1.11 & 0 & 0 & 1 & 3,13 & 12 & 37,5 & 6 & 18,8 & 3 & 9,38 & 5 & 15,60 & 5 & 15,60 & 4,44 \\
\hline $\mathrm{X} 1.12$ & 2 & 6,25 & 2 & 6,25 & 5 & 15,6 & 8 & 25 & 5 & 15,6 & 6 & 18,80 & 4 & 12,50 & 4,44 \\
\hline $\mathrm{X} 1.13$ & 0 & 0 & 1 & 3,13 & 4 & 12,5 & 7 & 21,9 & 7 & 21,9 & 4 & 12,50 & 9 & 28,10 & 5,13 \\
\hline Rata-rata & ruh & Varia & & & & & & & & & & & & & 4,53 \\
\hline
\end{tabular}

Sumber : Olah Data Primer 
Berdasarkan Tabel 8 di atas, mayoritas responden menjawab setuju. Dari nilai rata-rata keseluruhan (rata-rata variabel) sebesar 4,53 yang berada pada kategori kurang tinggi (nilai rata-rata antara 2,61 s.d 3,40) mengindikasikan bahwa sebagian besar responden mempersepsikan kurang tinggi pada variabel Keadilan Prosedural $\left(\mathrm{X}_{1}\right)$.

Dari nilai rata-rata indikator tertinggi sebesar 5.13 pada indikator ketigabelas $\left(\mathrm{X}_{1.13}\right)$, artinya indikator ketigabelas (Nilai dari penilaian prestasi yang saya peroleh mencerminkan apa yang pantas saya terima) pada variabel Keadilan Prosedural dinilai paling utama oleh reponden dibandingkan indikator yang lain pada variabel Keadilan Prosedural $\left(\mathrm{X}_{1}\right)$.

Kepemimpinan pada Badan Penanggulangan Bencana Daerah Provinsi Riau di Kota Pekanbaru.

Berdasarkan hasil perhitungan terhadap skor Kepemimpinan di Badan Penanggulangan Bencana Daerah Provinsi Riau di Kota Pekanbaru tersebut. Selanjutnya penyebaran distribusi frekuensi data Kepemimpinan pada Badan Penanggulangan Bencana Daerah Provinsi Riau dapat dilihat pada Tabel 9 berikut :
Berdasarkan Tabel 9. di atas, mayoritas responden menjawab setuju. Dari nilai rata-rata keseluruhan (rata-rata variabel) sebesar 4,76 yang berada pada kategori kurang tinggi (nilai rata-rata antara 2,61 s.d 3,40) mengindikasikan bahwa sebagian besar responden mempersepsikan kurang tinggi pada variabel Kepemimpinan $\left(\mathrm{X}_{2}\right)$.

Dari nilai rata-rata indikator tertinggi sebesar 4,97 pada indikator kelima $\left(\mathrm{X}_{2.5}\right)$, artinya indikator kelima (Pemimpin memiliki ketegasan didalam menerapkan setiap peraturan dan aturan yang ada.) pada variabel Kepemimpinan dinilai paling utama oleh reponden dibandingkan indikator yang lain pada variabel Kepemimpinan $\left(\mathrm{X}_{3}\right)$.

Kepuasan Kerja pada Badan Penanggulangan Bencana Daerah Provinsi Riau di Kota Pekanbaru

Berdasarkan hasil perhitungan terhadap skor Kepuasan Kerja di Badan Penanggulangan Bencana Daerah Provinsi Riau di Kota Pekanbaru tersebut. Selanjutnya penyebaran distribusi frekuensi data Kepuasan Kerja Badan Penanggulangan Bencana Daerah Provinsi Riau di Kota Pekanbaru dapat dilihat pada Tabel 10 berikut :

Tabel 9. Distribusi Frekuensi Skor Kepemimpinan $\left(\mathrm{X}_{2}\right)$

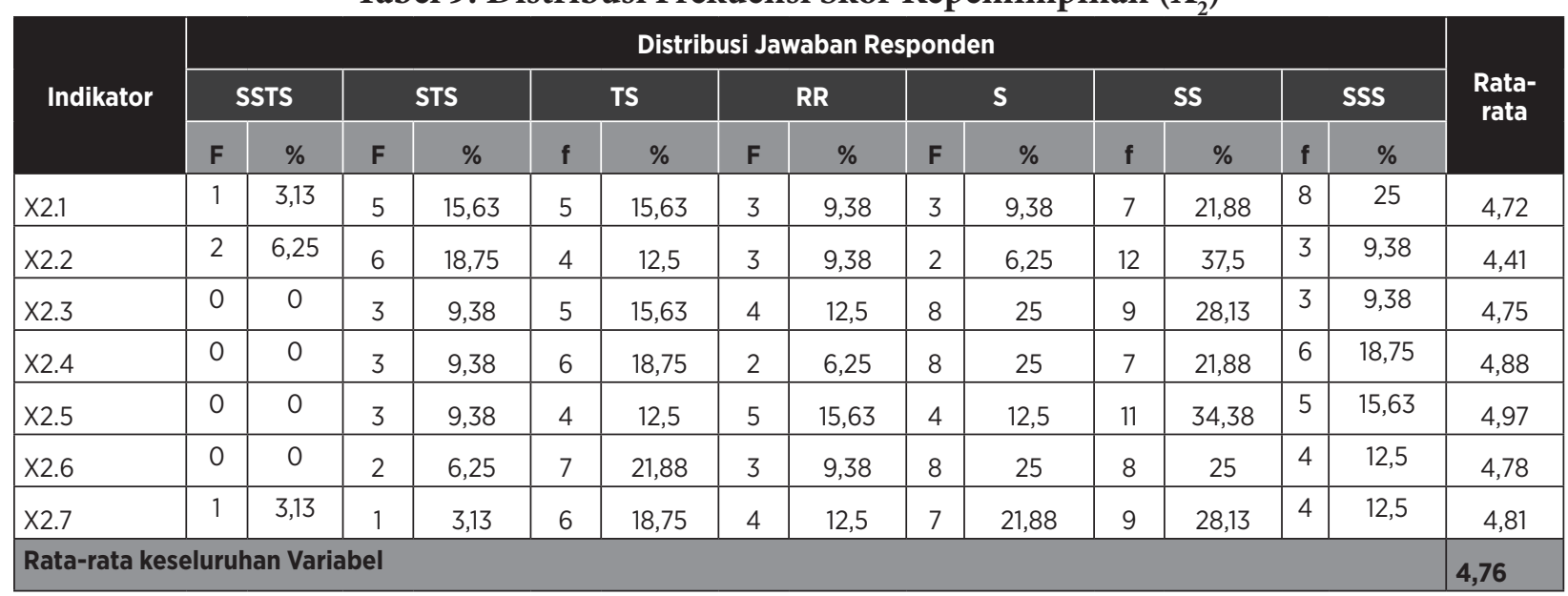

Sumber : Olah Data Primer 
Tabel 10. Distribusi Frekuensi Skor Kepuasan Kerja $\left(\mathrm{Y}_{1}\right)$

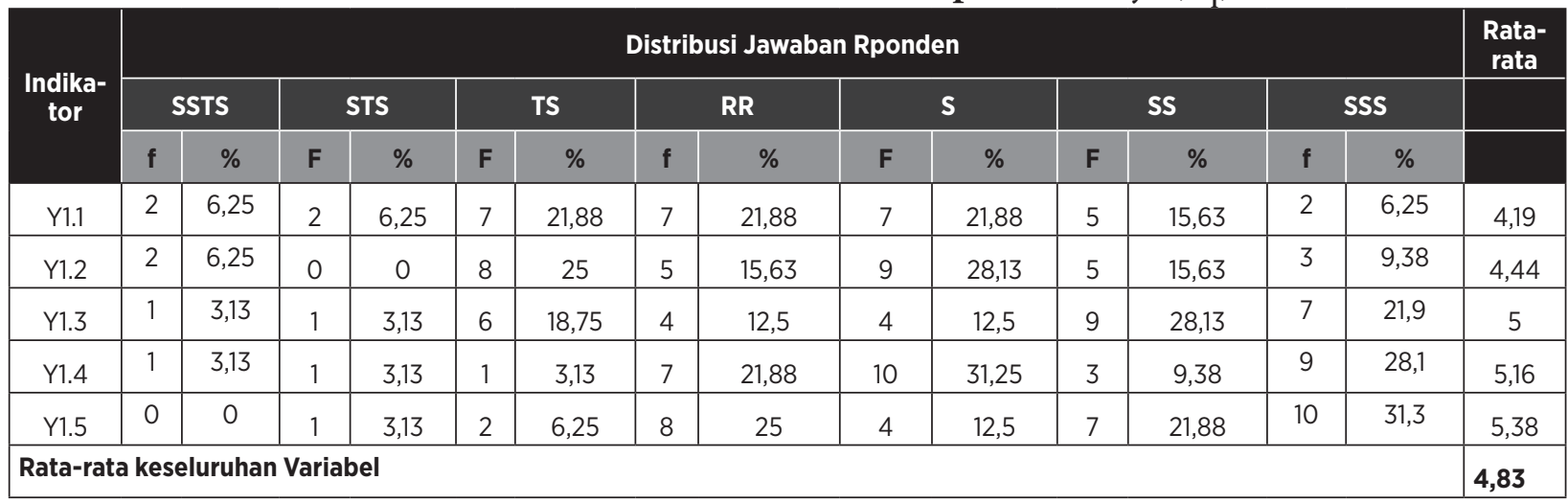

Sumber : Olah Data Primer

Berdasarkan Tabel 10 di atas, mayoritas responden menjawab setuju. Dari nilai rata-rata keseluruhan (rata-rata variabel) sebesar 4,83 yang berada pada kategori kurang tinggi (nilai rata-rata antara 2,61 s.d 3,40) mengindikasikan bahwa sebagian besar responden mempersepsikan kurang tinggi pada variabel Kepuasan Kerja $\left(\mathrm{Y}_{1}\right)$.

Dari nilai rata-rata indikator tertinggi sebesar 5,38 pada indikator kelima $\left(\mathrm{Y}_{1.5}\right)$, artinya indikator kelima (Pekerjaan yang diberikan sudah sesuai dengan keahlian dan keinginan saya) pada variabel Kepuasan Kerja dinilai paling utama oleh reponden dibandingkan indikator yang lain pada variabel Kepuasan Kerja $\left(\mathrm{Y}_{1}\right)$.

Kinerja Pegawai pada Badan Penanggulangan Bencana Daerah Provinsi Riau di Kota Pekanbaru.
Berdasarkan hasil perhitungan terhadap skor Kinerja Pegawai di Badan Penanggulangan Bencana Daerah Provinsi Riau di Kota Pekanbaru tersebut. Selanjutnya penyebaran distribusi frekuensi data Kinerja Pegawai pada Badan Penanggulangan Bencana Daerah Provinsi Riau di Kota Pekanbaru dapat dilihat pada Tabel 11 berikut :

Berdasarkan Tabel 11 di atas, mayoritas responden menjawab setuju. Dari nilai rata-rata keseluruhan (rata-rata variabel) sebesar 4,42 yang berada pada kategori kurang tinggi (nilai rata-rata antara 2,61 s.d 3,40) mengindikasikan bahwa sebagian besar responden mempersepsikan kurang tinggi pada variabel Kinerja (Y).

Dari nilai rata-rata indikator tertinggi sebesar 4,81 pada indikator kedelapan $\left(\mathrm{Y}_{2.7}\right)$. Artinya indikator ketujuh (Pegawai dapat meng-

Tabel 11. Distribusi Frekuensi Skor Kinerja Pegawai $\left(\mathrm{Y}_{2}\right)$

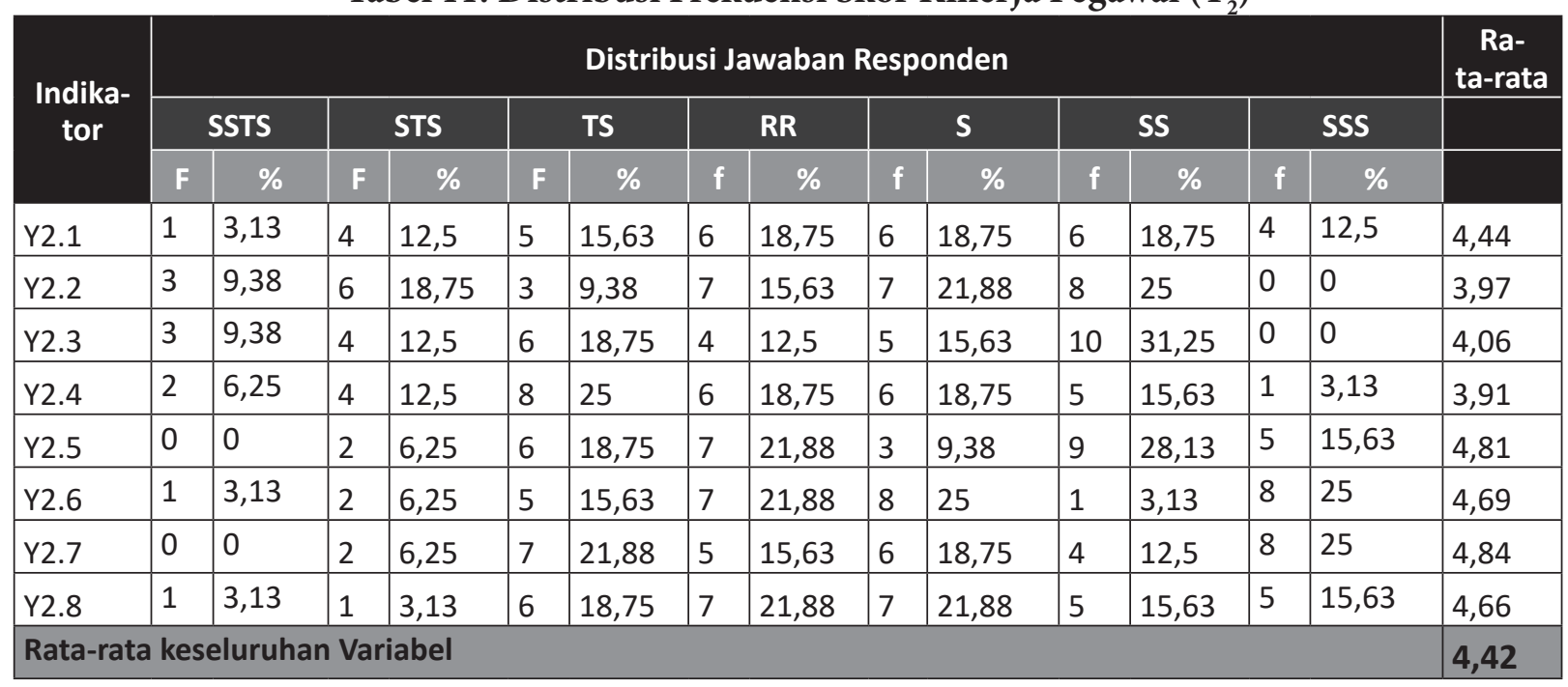


gunakan alat kerja dengan baik) pada variabel Kinerja dinilai paling utama oleh reponden dibandingkan indikator yang lain pada variabel Kinerja (Y).

\section{ANALISIS DATA}

\section{Uji Autokorelasi}

Untuk mendeteksi autokorelasi dalam penelitian ini maka digunakan uji Durbin Watson (DW) dengan melihat DW test.

Output yang dihasilkan dari SPSS :

Tabel 12. Model Summary Kepuasan Kerja Model Summary ${ }^{\mathrm{b}}$

\begin{tabular}{|l|c|l|l|l|l|}
\hline Model & $\mathbf{R}$ & $\begin{array}{c}\mathbf{R} \\
\text { Square }\end{array}$ & $\begin{array}{c}\text { Adjusted } \\
\text { R Square }\end{array}$ & $\begin{array}{c}\text { Std. Error of } \\
\text { the Estimate }\end{array}$ & $\begin{array}{c}\text { Durbin- } \\
\text { Watson }\end{array}$ \\
\hline 1 & $.816^{\mathrm{a}}$ & .667 & .644 & .71589 & 1.096 \\
\hline
\end{tabular}
a. Predictors: (Constant), KEPEMIMPINAN, KEADILAN PROSEDURAL

b. Dependent Variable: KEPUASAN KERJA

Tabel 13. Output Durbin Watson Model Summaryc

\begin{tabular}{|l|c|l|l|l|l|}
\hline Model & $\mathbf{R}$ & $\begin{array}{c}\mathbf{R} \\
\text { Square }\end{array}$ & $\begin{array}{l}\text { Adjusted } \\
\mathbf{R ~ S q u a r e}\end{array}$ & $\begin{array}{l}\text { Std. Error of } \\
\text { the Estimate }\end{array}$ & $\begin{array}{l}\text { Durbin- } \\
\text { Watson }\end{array}$ \\
\hline 1 & $.843^{\mathrm{a}}$ & .710 & .690 & .80830 & \\
\hline 2 & $.853^{\mathrm{b}}$ & .728 & .699 & .79630 & 1.117 \\
\hline
\end{tabular}

a. Predictors: (Constant), KEPEMIMPINAN, KEADILAN PROSEDURAL

b. Predictors: (Constant), KEPEMIMPINAN, KEADILAN PROSEDURAL, KEPUASAN KERJA

c. Dependent Variable: KINERJA

Sumber : Olah Data Primer

Dari perhitungan SPSS for windows, nilai Durbin Watson (DW) sebesar 1,117 Nilai DW terletak antara -2 sampai dengan +2 dengan kesimpulan tidak ada autokorelasi antar masing-masing variabel bebas, sehingga model regresi yang terbentuk dari nilai variabel terikat hanya dijelaskan oleh variabel bebas.

\section{Uji Multikolinearitas}

Uji multikolinieritas dimaksudkan untuk mengetahui adanya hubungan yang sempurna antar variabel dalam model regresi. Untuk mendeteksi adanya multikolinieritas dalam penelitian ini maka digunakan korelasi matriks. Dari perhitungan estimasi korelasi matrik dengan program SPSS dapat dilihat pada tabel berikut :
Tabel 14. Output Coefficients

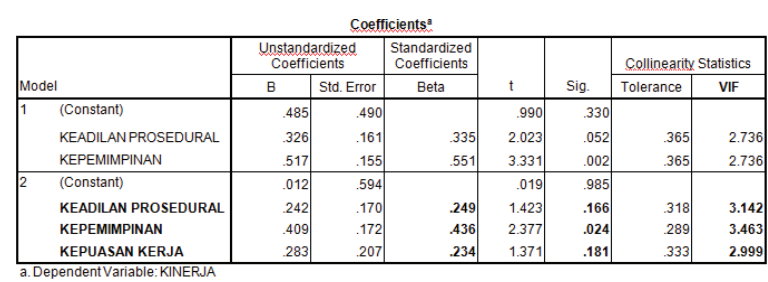

Analisis Diagram Jalur untuk Variabel Keadilan Prosedural, Kepemimpinan, Kepuasan Kerja dan Kinerja Pegawai.

Setiap individu Pegawai memiliki persepsi yang berbeda dalam memberikan penilaian tentang Keadilan Prosedural, Kepemimpinan, Kepuasan Kerja dan Kinerja Pegawai. Berdasarkan penilaian tersebut akan dapat dilihat bentuk hubungan yang terjadi antara Keadilan Prosedural terhadap Kepuasan Kerja, Kepemimpinan terhadap Kepuasan Kerja, Kepuasan Kerja terhadap Kinerja Pegawai serta hubungan antara Keadilan Prosedural, Kepuasan Kerja, dan Kepemimpinan secara bersama-sama terhadap Kinerja Pegawai.

Tabel 15. Output Coefficients Kepuasan Kerja

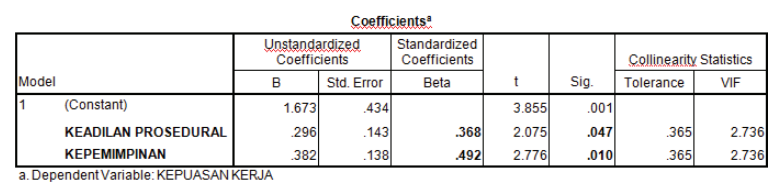

Tabel 16. Output Coefficients Kinerja

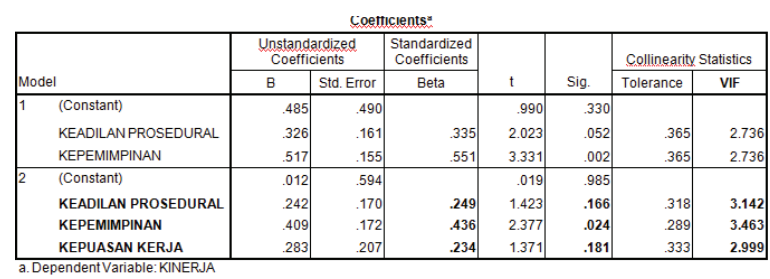

\section{PENGUJIAN HIPOTESIS}

Pengaruh Keadilan Prosedural terhadap Kinerja pada Pegawai Badan Penanggulangan Bencana Daerah Provinsi Riau di Kota Pekanbaru. 
Tabel 17. Analisis Anova

\begin{tabular}{|ll|r|r|r|r|r|}
\hline Model & & Sum of Squares & \multicolumn{1}{|c|}{ df } & Mean Square & F & \multicolumn{1}{c|}{ Sig. } \\
\hline 1 & Regression & 46.350 & 2 & 23.175 & 35.471 & $.000^{\circ}$ \\
& Residual & 18.947 & 29 & .653 & & \\
& Total & 65.297 & 31 & & & \\
\hline 2 & Regression & 47.543 & 3 & 15.848 & 24.992 & $.000^{\circ}$ \\
& Residual & 17.755 & 28 & .634 & & \\
& Total & 65.297 & 31 & & & \\
\hline
\end{tabular}

a. Predictors: (Constant), KEPEMIMPINAN, KEADILANPROSEDURAL

b. Predictors: (Constant), KEPEMIMPINAN, KEADILAN PROSEDURAL, KEPUASAN KERJA

c. Dependent Variable: KINERJA

Berdasarkan tabel 18 menjelaskan hubungan variabel Keadilan Prosedural terhadap Kinerja pada Pegawai Badan Penanggulangan Bencana Daerah Provinsi Riau di Kota Pekanbaru memiliki thitung sebesar 1,423 lebih besar dari t tabel sebesar 1,360 dengan nilai sign $=0,166$, dan tingkat kesalahan (alpha) sebesar 0,05 , menyatakan H0 ditolak. Kesimpulannya bahwa terdapat hubungan yang signifikan antara Keadilan Prosedural terhadap Kinerja pada Pegawai Badan Penanggulangan Bencana Daerah Provinsi Riau di Kota Pekanbaru.

Pengaruh Keadilan Prosedural terhadap Kinerja, melalui Kepuasan Kerja pada Pegawai Badan Penanggulangan Bencana Daerah Provinsi Riau di Kota Pekanbaru.

Dari tabel 17 dapat dilihat bahwa Diketahui $\mathrm{F}$ hitung sebesar 24,992 dan p-value (Sig.) = 0,000 lebih kecil dari 0,05. Artinya adalah bahwa variabel Kepuasan Kerja berpengaruh secara parsial hubungan antara Keadilan Prosedural dengan Kinerja, sehingga $\mathrm{H} 1$ diterima dan Ho ditolak. Kesimpulannya terdapat hubungan Keadilan Prosedural terhadap Kinerja melalui Kepuasan Kerja Pegawai Badan Penanggulangan Bencana Daerah Provinsi Riau di Kota Pekanbaru.

Pengaruh Kepemimpinan terhadap Kinerja pada Pegawai Badan Penanggulangan

\section{Bencana Daerah Provinsi Riau di Kota Pe- kanbaru.}

Berdasarkan tabel 17 menjelaskan hubungan variabel Kepemimpinan terhadap Kinerja pada Pegawai Badan Penanggulangan Bencana Daerah Provinsi Riau di Kota Pekanbaru memiliki t hitung sebesar 2,377 lebih besar dari t tabel sebesar 1,360 , nilai sign $=0,024$, dan tingkat kesalahan (alpha) sebesar 0,05 menyatakan H0 diterima. Kesimpulannya bahwa terdapat hubungan yang signifikan antara Kepemimpinan terhadap Kinerja pada Pegawai Badan Penanggulangan Bencana Daerah Provinsi Riau di Kota Pekanbaru.

Pengaruh Kepemimpinan terhadap Kinerja melalui Kepuasan Kerja pada Pegawai Badan Penanggulangan Bencana Daerah Provinsi Riau di Kota Pekanbaru.

Dari tabel 17 dapat dilihat bahwa Diketahui $\mathrm{F}$ hitung sebesar 35,471 dan p-value (Sig.) $=0,000$ lebih kecil dari 0,05. Artinya adalah bahwa variabel Kepuasan Kerja berpengaruh secara parsial hubungan antara Kepemimpinan dengan Kinerja, sehingga H1 diterima dan Ho ditolak. Kesimpulannya terdapat hubungan Kepemimpinan terhadap Kinerja melalui Kepuasan Kerja Pegawai Badan Penanggulangan Bencana Daerah Provinsi Riau di Kota Pekanbaru. 
Pengaruh Keadilan Prosedural dan Kepemimpinan terhadap Kinerja melalui Kepuasan Kerja Pegawai Badan Penanggulangan Bencana Daerah Provinsi Riau di Pekanbaru

Tabel 18. Pengaruh Kepemimpinan dan Keadilan Prosedural

\begin{tabular}{|c|c|c|c|c|c|c|}
\hline \multicolumn{7}{|c|}{ Coefficients } \\
\hline \multirow[b]{2}{*}{ Model } & & \multicolumn{2}{|c|}{ Unstandardized Coefficients } & $\begin{array}{c}\text { Standardized } \\
\text { Coefficients }\end{array}$ & \multirow[b]{2}{*}{$t$} & \multirow[b]{2}{*}{ Sig. } \\
\hline & & $\mathrm{B}$ & Std. Error & Beta & & \\
\hline 1 & $\begin{array}{l}\text { (Constant) } \\
\end{array}$ & .880 & .531 & & \begin{tabular}{c|c|}
1.657 \\
\end{tabular} & .108 \\
\hline & KEPEMIMPINAN & .767 & .106 & .797 & 7.217 & .000 \\
\hline
\end{tabular}

Dari tabel 18 dapat dilihat bahwa Diketahui t hitung sebesar 7,217 lebih besar dari t tabel 1,360 dengan significant sebesar 0,000 dan tingkat kesalahan (alpha) sebesar 0,05.. Artinya adalah bahwa variabel Kepemimpinan berhubungan terhadap variabel Keadilan Prosedural, sehingga $\mathrm{H} 1$ diterima dan Ho ditolak.

\section{PEMBAHASAN}

Dari pengujian hipotesis yang dilakukan dengan menggunakan analisis jalur, dan sesuai dengan tujuan penelitian yang dibuat sebelumnya maka dapat di uraikan sebagai berikut :

Pengaruh Keadilan Prosedural terhadap Kinerja Pegawai Badan Penanggulangan Bencana Daerah Provinsi Riau

Tabel 19. Model Summary

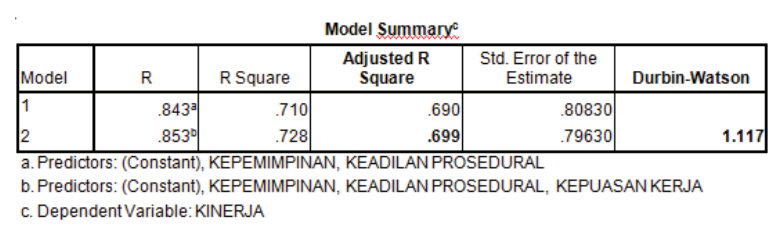

Faktor Keadilan Prosedural, dalam penelitian ini terbukti memberikan kontribusi yang sangat signifikan dalam membangun Kinerja Pegawai pada Badan Penanggulangan Bencana Daerah Provinsi Riau di Kota Pekanbaru sebesar $69,9 \%$, sedangkan sisanya $30,1 \%$ yang bisa saja dihubungkan oleh faktor-faktor lain yang tidak dimasukan kedalam model ini. Faktor Keadilan Prosedural, memberikan kontribusi yang besar yang artinya bahwa Keadilan Prosedural, merupakan faktor yang menjadi penting dalam meningkatkan Kinerja yang ada di Badan Penanggulangan Bencana Daerah Provinsi Riau di Kota Pekanbaru. Hal ini disebabkan pemahaman tentang keadilan prosedural sangat penting karena hal ini mempengaruhi beragam sikap dan perilaku yang berbeda. Keragaman konsekuensi dengan diterapkannya keadilan prosedural akan mengarah pada nilai yang disetujui oleh individu. . Keadilan prosedural sangatlah penting dalam riset efektivitas organisasi, karena efek dari keadilan prosedural akan berdampak pada perilaku anggota perusahaan dan kinerja anggota perusahaan tersebut, dimana semakin tinggi keadilan prosedural, maka semakin tinggi juga kinerja pegawai tersebut..

Pengujian hipotesis kedua (H2) semakin tinggi keadilan prosedural semakin tinggi kinerja organisasi, menunjukan hasil positif dan signifikan terhadap kinerja organisasi, hal ini menunjukan bahwa persepsi keadilan prosedural akan berpengaruh terhadap kinerja organisasi.. Hasil penelitian ini konsisten dengan hasil penelitian Libby (1999), Ulupui (2005) dan I Gusti Ngurah Agung Wiryanata (2014).

Pengaruh Keadilan Prosedural Terhadap Kinerja melalui Kepuasan Kerja Pegawai Badan Penanggulangan Bencana Daerah Provinsi Riau

Tabel 20. Pengaruh Keadilan Prosedural terhadap Kinerja melalui Kepuasan Kerja

\begin{tabular}{|c|c|c|c|c|c|}
\hline \multicolumn{6}{|c|}{ Model Summary } \\
\hline Model & $\mathrm{R}$ & R Square & Adjusted R Square & $\begin{array}{l}\text { Std. Error of the } \\
\text { Estimate }\end{array}$ & Durbin-Watson \\
\hline 1 & $.816^{3}$ & $\begin{array}{r}.667 \\
\end{array}$ & $\begin{array}{r}.644 \\
\end{array}$ & 7.71589 & 1.096 \\
\hline
\end{tabular}

Faktor Keadilan Prosedural, dalam penelitian ini terbukti keadilan prosedural melalui kepuasan kerja memberikan kontribusi yang sangat signifikan dalam membangun Kinerja 
Pegawai pada Badan Penanggulangan Bencana Daerah Provinsi Riau di Kota Pekanbaru sebesar $64,4 \%$, sedangkan sisanya $36,6 \%$ yang bisa saja dipengaruhi oleh faktor-faktor lain yang tidak dimasukan kedalam model ini.

Faktor Keadilan Prosedural melalui kepuasan kerja memberikan kontribusi yang besar terhadap kinerja pegawai yang artinya bahwa Keadilan Prosedural melalui kepuasan kerja merupakan faktor yang menjadi penting dalam meningkatkan Kinerja yang ada di Badan Penanggulangan Bencana Daerah Provinsi Riau di Kota Pekanbaru. Untuk mencapai kepuasan kerja, perusahaan harus memperhatikan keadilan distributif dan keadilan prosedural yang ada didalam organisasi. Berdasarkan hasil analisis deskriptif dapat diketahui bahwa responden memberikan penilaian adil terhadap penerapan keadilan prosedural, dan memberikan penilaian cukup adil pada kinerja, dan yang terakhir memberikan penilaian puas terhadap kepuasan kerja yang selama ini responden rasakan.

Hasil penelitian ini konsisten dengan hasil penelitian Hartanto, Henry Tri (2008) dimana terdapat pengaruh signifikan antara keadilan prosedural terhadap kinerja manajerial dengan kepuasan kerja sebagai variabel intervening.

Pengaruh Kepemimpinan Terhadap Kinerja Pegawai Badan Penanggulangan Bencana Daerah Provinsi Riau

Berdasarkan tabel 18 diatas, Faktor Kepemimpinan, dalam penelitian ini terbukti memberikan kontribusi yang sangat signifikan dalam membangun Kinerja Pegawai pada Badan Penanggulangan Bencana Daerah Provinsi Riau di Kota Pekanbaru sebesar 69\%, sedangkan sisanya $31 \%$ yang bisa saja dipengaruhi oleh faktor-faktor lain yang tidak dimasukan kedalam model ini. Faktor Kepemimpinan, memberikan kontribusi yang besar yang artinya bahwa Kepemimpinan, merupakan faktor yang menjadi penting dalam meningkatkan Kinerja yang ada di Badan Penanggulangan Bencana Daerah Provinsi Riau di Kota Pekanbaru. Kepemimpinan adalah kemampuan yang sanggup meyakin- kan orang lain dan memotivasi individu-individu supaya bekerjasama dibawah pimpinannya sebagai suatu tim untuk mencapai tujuan perusahaan yang diinginkan. Kepemimpinan juga untuk mengkoordinasikan perintah atasan kepada bawahan dengan menjangkau dari puncak sampai kebawah seluruh badan usaha. Pentingnya kepemimpinan dalam berorganisasi dimaksudkan untuk mencapai tujuan organisasi secara efektif dan efisien.

Pengaruh signifikan kepemimpinan Terhadap Kinerja Pegawai Badan Penanggulangan Bencana Daerah Provinsi Riau juga didukung oleh penelitian Ratna Yulia Wijayanti (2010) dengan hasil penelitian bahwa variabel kepemimpinan secara parsial mempunyai pengaruh yang signifikan terhadap kinerja PNS Dinas Pendidikan Kabupaten Kudus.

Pengaruh Kepemimpinan Terhadap Kinerja melalui Kepuasan Kerja Pegawai Badan Penanggulangan Bencana Daerah Provinsi Riau

Berdasarkan tabel 18 Faktor Keadilan Prosedural, dalam penelitian ini terbukti kepemimpinan melalui kepuasan kerja memberikan kontribusi yang sangat signifikan dalam membangun Kinerja Pegawai pada Badan Penanggulangan Bencana Daerah Provinsi Riau di Kota Pekanbaru sebesar 64,4\%, sedangkan sisanya $36,6 \%$ yang bisa saja dipengaruhi oleh faktor-faktor lain yang tidak dimasukan kedalam model ini. Faktor Kepemimpinan melalui kepuasan kerja memberikan kontribusi yang besar terhadap kinerja pegawai yang artinya bahwa Kepemimpinan melalui kepuasan kerja merupakan faktor yang menjadi penting dalam meningkatkan Kinerja yang ada di Badan Penanggulangan Bencana Daerah Provinsi Riau di Kota Pekanbaru.

Organisasi merupakan sekumpulan orang yang berkerja secara bersama-sama dalam mencapai suatu tujuan tertentu. Komponen utama dalam suatu organisasi adalah anggota atau karyawan yang saling berintaraksi. Namun anggota saja tidak cukup, karena salah satu ciri 
yang harus dimiliki suatu organisasi adanya seorang pemimpin. Begitu juga dalam konteks organisasi perusahaaan. Setiap perusahaan mempunyai seorang pemimpin. pemimpin (leader) adalah bertanggung jawab terhadap segala perubahan yang terjadi, menetapkan visi dan mengaplikasikannya dalam perusahaan. Seorang pemimpin harus tahu apa yang harus dilakukan untuk membawa perusahaannya ke depan, sehingga perusahaan bisa sukses. Untuk membuat sukses suatu perusahaan, seorang pemimpin tidak bisa bekerja seorang diri, perlu didukung oleh karyawan. Untuk memperoleh dukungan dari para karyawan tidak mudah, seorang pemimpin harus memperhatikan aspirasi, dan kebutuhan para karyawan tersebut, untuk itu seorang pemimpin harus menerapkan keadilan prosedural didalam gaya kepemimpinannya. Hal ini berguna untuk hal yang berkaitan dengan kebijakan atau keputusan dalam perusahaan., sehingga disimpulkan terdapat pengaruh yang signifikan antara Keadilan Prosedural terhadap Kepemimpinan para pegawai Badan Penanggulangan Bencana Daerah Provinsi Riau di Kota Pekanbaru.

Pengaruh signifikan kepemimpinan Terhadap Kinerja Pegawai melalui Kepuasan Kerja Badan Penanggulangan Bencana Daerah Provinsi Riau juga didukung oleh penelitian Lund (2008) dan Rani Mariam (2009) dengan hasil penelitian bahwa variabel kepemimpinan secara parsial mempunyai pengaruh yang signifikan terhadap kinerja karyawan melalui kepuasan kerja.

Pengaruh Keadilan Prosedural dan Kepemimpinan Terhadap Kinerja melalui Kepuasan Kerja Pegawai Badan Penanggulangan Bencana Daerah Provinsi Riau

Tabel 21. Model Summary Kepemimpinan

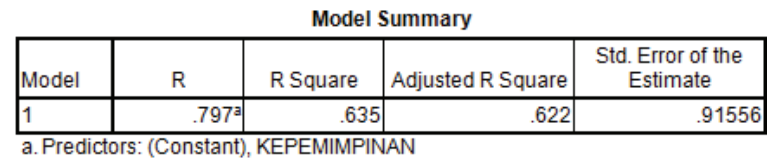

Faktor Kepemimpinan dalam penelitian ini terbukti berhubungan dengan Keadilan Prosedural sebesar $62,2 \%$, sedangkan sisanya $37,8 \%$ yang bisa saja dihubungani oleh faktor-faktor lain yang tidak dimasukan kedalam model ini. Faktor Keadilan Prosedural berhubungan terhadap Kepemimpinan yang artinya bahwa Keadilan Prosedural dan Kepemimpinan merupakan faktor yang menjadi penting dalam meningkatkan Kinerja yang ada di badan penanggulangan bencana daerah provinsi riau di kota pekanbaru. Pemimpin yang efektif akan dapat menjalankan fungsinya dengan baik, tidak hanya ditunjukkan dari kekuasaan yang dimiliki tetapi juga ditunjukkan pula oleh perhatian pemimpin terhadap kesejahteraan dan kepuasan karyawan terhadap pemimpinnya dan peningkatan kualitas karyawan, terutama sikap mengayomi yang ditunjukkan untuk menguatkan kemauan karyawan dalam melaksanakan tugas guna mencapai sasaran organisasi. Keadilan prosedural serta kepuasan kerja secara bersama-sama berpengaruh terhadap kinerja pegawai. Kepuasan kerja memediasi pengaruh keadilan prosedural terhadap kinerja pegawai.

Hasil penelitian ini konsisten dengan hasil penelitian Hartanto, Henry Tri (2008) , Lund (2008) dan Rani Mariam (2009) dengan hasil penelitian bahwa variabel keadilan prosedural, kepemimpinan secara parsial mempunyai pengaruh signifikan terhadap kinerja manajerial dengan kepuasan kerja sebagai variabel intervening.

\section{KESIMPULAN DAN SARAN Kesimpulan}

1. Keadilan Prosedural berpengaruh secara signifikan terhadap Kinerja pegawai di Badan Penanggulangan Bencana Daerah Provinsi Riau di Kota Pekanbaru. Berdasarkan analisis statistik yang menyatakan hubungannya adalah kuat, sehingga disimpulkan terdapat pengaruh yang signifikan antara Keadilan Prosedural terhadap Kinerja para Pegawai Badan Penanggulangan Bencana Daerah 
Provinsi Riau di Kota Pekanbaru. Keadilan prosedural sangatlah penting dalam riset efektivitas organisasi, karena efek dari keadilan prosedural akan berdampak pada perilaku anggota perusahaan dan kinerja anggota perusahaan tersebut, dimana semakin tinggi keadilan prosedural, maka semakin tinggi juga kinerja pegawai tersebut.

2. Keadilan Prosedural berpengaruh signifikan terhadap Kinerja Pegawai melalui Kepuasan Kerja pegawai di Badan Penanggulangan Bencana Daerah Provinsi Riau di Kota Pekanbaru. Berdasarkan analisis statistik yang menyatakan hubungannya adalah kuat, sehingga disimpulkan terdapat pengaruh yang signifikan antara interaksi Keadilan Prosedural terhadap kinerja pegawai melalui kepuasan kerja para pegawai Badan Penanggulangan Bencana Daerah Provinsi Riau di Kota Pekanbaru. Untuk mencapai kepuasan kerja, perusahaan harus memperhatikan keadilan distributif dan keadilan prosedural yang ada didalam organisasi. Berdasarkan hasil analisis deskriptif dapat diketahui bahwa responden memberikan penilaian adil terhadap penerapan keadilan prosedural, dan

3. Memberikan penilaian cukup adil pada kinerja, dan yang terakhir memberikan penilaian puas terhadap kepuasan kerja yang selama ini responden rasakan. Kepemimpinan berpengaruh secara signifikan terhadap Kinerja pegawai di Badan Penanggulangan Bencana Daerahnya Provinsi Riau di Kota Pekanbaru. Berdasarkan analisis statistik yang menyatakan hubungannya adalah cukup kuat, sehingga disimpulkan terdapat pengaruh yang signifikan antara Kepemimpinan terhadap Kinerja para Pegawai Badan Penanggulangan Bencana Daerah Provinsi Riau di Kota Pekanbaru.. Dapat dikatakan pemimpin merupakan penggerak dari keberhasilan kerja organisasi. Dengan demikian kepemimpinan merupakan sentral dalam kepengurusan or- ganisasi, tumbuh kembangnya organisasi, mati hidupnya organisasi, senang tidaknya kepemimpinan yang diterapkan dalam organisasi yang bersaing. Tidak dipungkiri lagi bahwa pemimpin hanya menjalankan kepemimpinannya saja dimana yang melakukan sebagaian besar pekerjaan tersebut yaitu para bawahan (karyawan) tetapi yang terkenal adalah pimpinannya. Dapat disimpulkan bahwa kepemimpinan sangat berpengaruh terhadap kinerja karyawan.

4. Kepemimpinan berpengaruh secara signifikan terhadap Kinerja melalui Kepuasan Kerja Pegawai di Badan Penanggulangan Bencana Daerah Provinsi Riau di Kota Pekanbaru. Berdasarkan analisis statistik yang menyatakan hubungannya adalah kuat, sehingga disimpulkan terdapat pengaruh yang signifikan antara Keadilan Prosedural terhadap Kepemimpinan para pegawai Badan Penanggulangan Bencana Daerah Provinsi Riau di Kota Pekanbaru. Keadilan prosedural memiliki dampak bagi kondisi perusahaan terutama bagaimana relasi yang tercipta antara karyawan dan pemimpin. .

5. Keadilan Prosedural dan Kepemimpinan berpengaruh secara signifikan terhadap Kinerja melalui Kepuasan Kerja Pegawai di Badan Penanggulangan Bencana Daerah Provinsi Riau di Kota Pekanbaru. Berdasarkan analisis statistik yang menyatakan hubungannya adalah kuat, sehingga disimpulkan terdapat pengaruh yang signifikan antara interaksi Kepemimpinan terhadap Kinerja melalui kepuasan kerja para pegawai Badan Penanggulangan Bencana Daerah Provinsi Riau di Kota Pekanbaru. Kepemimpinan yang baik secara tidak langsung dapat mempengaruhi kinerja pegawai perusahaan. Kondisi kerja lebih kondusif, efektif dan efeisien dan pada akhirnya akan meningkatkan kinerja pegawai dalam meningkatkan produktivitas Perusahaan. Keadilan prosedural dan kepuasan kerja secara bersama-sama berpengaruh terha- 
dap kinerja pegawai. Keadilan prosedural serta kepuasan kerja secara bersama-sama berpengaruh terhadap kinerja pegawai. Kepuasan kerja memediasi pengaruh keadilan prosedural terhadap kinerja pegawai.

\section{Saran}

Hal-hal yang dapat disarankan berdasarkan hasil penelitian dan pembahasan mengenai pengaruh Keadilan Prosedural, Kepemimpinan dan Kepuasan Kerja terhadap kinerja Pegawai dan Hubungan Keadilan Prosedural dan Kepemimpinan terhadap Kepuasan Kerja pada Pegawai Badan Penanggulangan Bencana Daerah Provinsi Riau di Kota Pekanbaru meliputi :

1. Bagi peneliti selanjutnya sebaiknya kuesioner setiap variabel menggunakan kuesioner baru yang sesuai dengan keadaan yang ada.

2. Penelitian selanjutnya disarankan untuk memperluas area penelitian. Hal ini diperlukan untuk meningkatkan akurasi hasil yang diperoleh dimasa yang akan datang dapat lebih sempurna dari penelitian ini.

3. Penelitian selanjutnya perlu ditambahkan metode wawancara langsung pada masingmsing responden dalam upaya mengumpulkan data jika memungkinkan, sehingga dapat menghindari kemungkinan responden tidak objektif dalam mengisi kuesioner.

4. Faktor yang paling mempengaruhi Kinerja adalah Kedilan Prosedural sehingga sifat aturan formal, penjelasan terhadap prosedur dan pengambilan keputusan, serta perlakuan interpersonal harus ditingkatkan oleh Institusi sehingga dapat meningkatkan Kinerja.

5. Faktor yang paling mempengaruhi Kepuasan Kerja adalah Kedilan Prosedural sehingga sifat aturan formal, penjelasan terhadap prosedur dan pengambilan keputusan, serta perlakuan interpersonal harus ditingkatkan oleh Institusi sehingga dapat meningkatkan Kinerja.

6. Pada faktor Kepemimpinan diharapkan atasan (Pejabat Esselon) dapat melaksanakan kepemipinan dengan sebaik-baiknya sehingga dapat meningkatkan kinerja pegawai.

7. Kepuasan Kerja mutlak harus menjadi catatan tersendiri untuk meningkatkan kinerja Pegawai Badan Penanggulangan Bencana Daerah Provinsi Riau di Kota Pekanbaru.

\section{DAFTAR PUSTAKA}

Annisafitria, 2008, Penerapan Balanced Scorecard Sebagai Tolok Ukur Penilaian Kinerja Pada Badan Usaha Berbentuk Rumah Sakit (Studi Kasus Pada Rumah Sakit Kristen Tayu-Pati), Pati.

Badarudin Latif, Achmad, 2007, Hubungan Antara Keadilan Prosedural dan kinerja Manajerial Dengan Partisipasi Anggaran Sebagai Variabel Intervening (Penelitian Terhadap Manajer Perusahaan Manufaktur Di Jawa Tengah), Tesis Fakultas Ekonomi Universitas Diponegoro. http://eprints.undip. ac.id/6804/1/Achmad-Badarudin-latif.pdf.

Bilmoneva L., dan Kusnanto H., 2006, Hubungan Antara Komitmen Terhadap Organisasi Dengan Kinerja Dosen Pembelajaran Klinik di Akper Swasta di Pekanbaru. Magister Kebijakan dan Manajemen Pelayanan Kesehatan. KMPK Universitas Gadjah Mada, Working Paper Series No. 11, First Draft.

Davis, Keith and Newton W.1995. Perilaku dalam Organiasasi. Jilid I edisi 7, Penerbit Erlangga, Jakarta.

Faturochman, 1999, Buletin Psikologi, Tahun VII, Jakarta.

Ghozali, Imam, 2005, Aplikasi Analisis Multivariate Dengan Program SPSS, Semarang: Badan Penerbit Universitas Diponegoro.

Greenberg, J. 1996. Reactions to Procedural Injustice in Payment Distributions: do the ends justify the means, Journal of Applied Psy- 
chology, 72, pp. 55-61

Handoko, T. Hani. 2003. Manajemen Personalia, Edisi Revisi, Yogyakarta: Gadjah Mada University Press

Ikhsan, Arfan dan Ishak, Muhammad. 2005. Akuntansi Keprilakuan. Jakarta : Salemba Empat.

Konovsky,M., S. Pugh, 1994. Citizenship Behaviour and Social Exchange. Academy of Management Journal. 37 656-669.

Konovsky,M., R. Folger, 1989. The Academy of Management Journal, Vol.32, No.1

Lau \& Aggleton, Leventhal, G.S. (2008). What Should be Done With Equity theory? New Approaches to The Study of Fairness in Social Relationships In K. Gergen, M. Greenberg \& R. Willis (eds), Social Exchanges: Advances in Theory and Research pp. 25755. New York: Plenum Press.

Lenvinne, Charles H, 1990, Publik administration, Challenges, Choices, Consequences, Scott Forman/Little Brown Higher Education: Glenview, Illinois.

Luthans, Fred, 2006, Perilaku Organisasi, Edisi Sepuluh, Yogyakarta: C.V Andi Offset.

Malgorzota, Roekwitalska, 2009, Journal of Intercultural Management, Vol 1 No 1. Politechnica Gadenska.

Mangkunegara AA. Anwar Prabu, 2007, Evaluasi Kinerja SDM, Jakarta : PT. Refika Aditama. Bandung.

Mc. Farlin Dean., Sweeney Paul, 2006, International Management, Third Edition. University of Daytin

Meyer, JP, \& Allen N.J, 1991, A Three Component Conceptualization of Organizational Commitment, Human Resource Management Review

Mitchel, T.,R, Matching Motivational Strategies with Organizational Context, CT JAI Press, 1997.

Moers, Frank, 2000, Keuangan dan Non Keuangan dan Manajerial Ukuran Kinerja Jangka Pendek, Fakultas Ekonomi dan Administrasi Maastricht University, Netherland Belan- da. http://arno.unimaas.nl/show.cgi?fid=526 Muhadi, 2007, Analisis Hubungan Kepuasan Kerja Terhadap Kepemimpinan dalam Memhubungani Kinerja Karyawan (Studi Pada Karyawan Administrasi Universitas Diponogoro. Undip. Semarang.

Mulyadi, 2007, Sistem Perencanaan dan Pengendalian Manajemen (Sistem Pelipatganda Kinerja Perusahaan); Edisi Ketiga, Jakarta: Salemba Empat.

Mulyasari, Sugiri, 2004, Hubungan Keadilan Persepsion, Komitmen Pada Tujuan, dan $\mathrm{Job}$ Relevant Information, terhadao $\mathrm{Hu}$ bungan Antara Penganggaran Partisipatif dan Kinerja Manager, Univeritas Gadjah Mada.

Perry L, 1981. James \& Angle L, Harold, Administrative Science Quarterly, Vol. 26, No. 1.

Prawirosentono, Suryadi. 2008. Kebijakan Kinerja Karyawan, BPFE, Yogyakarta.

Purwanto. Hubungan Partisipasi Penyusunan Anggaran Terhadap Kinerja Pemerintah Daerah Dengan Keadilan Distributif, Keadilan Prosedural dan Goal Commitment Sebagai Variabel Moderating ; Studi Pada Pemerintah Kabupaten Banjarnegara. Tesis Fakultas Ekonomi Universitas Diponegoro. www.google.com.

Rozkwitalska,2009 Malgorzata, Journal of Intercultural Management Vol. 1, Politechnica Gdanzka.

Rosidah. Kompetensi Kinerja Pengembangan Sumber Daya Manusia, Semarang. http:// www.damandiri.or.id/file/rosidahunairbab2.pdf

Robbins, Stephen P., 1996, Perilaku Organisasi, Edisi 10 Bahasa Indonesia, PT. Indeks Kelompok Gramedia.

Salim, Ratminto dan Atik Septi Winarsih, 2005, Manajemen Pelayanan. Cetakan ke-I, Jogjakarta.

Sekaran, Umar, 2007, Research Methods for Business (Metodologi Penelitian Untuk Bisnis, Jakarta: Salemba Empat.

Siagian, Sondang P, 1996. Manajemen Sumber 
Daya Manusia, Jakarta : Bumi Aksara.

Soetriono, dan Hanafie, Rita. 2007, Filsafat Ilmu dan Metodologi Penelitian. Yogyakarta: C.V Andi Offset.

Sudjatmiko, Steve, 2009. Mengapa Departemen SDM Dibenci. PT. Gramedia Pustaka Utama

Sudarwan, Danim. 2004. Motivasi, Kepemimpinan dan Efektivitas Kelompok, cet. Ke-1, Jakarta: PT. Rineka Cipta.

Tang, Thomas Li-Ping and Linda J. SarsfieldBaldwin, "Distributive and Procedural Justice as Related to Satisfaction and Commitment", Sam Advance Management Journal, 25-31, 1996.

Tyler R, Tom \& Blader L. 2003, Steven, A FourComponent Model of Procedural Justice: Defining the Meaning of A Fair Process.

Wasisto, Sholihin. 2004, Peran Partisipasi Anggaran Dalam Hubungan antara Keadilan Prosedural dengan Kinerja Manajerial dan Kepuasan Kerja. Universitas Gadjah Mada

Wjayanti, Ratna Yulia. 2010, Analisis Manajemen Vol 4 No.2: Hubungan Kepemimpinan, Motivasi, dan Kepemimpinan Terhadap Kinerja PNS di Lingkungan Organisasi Dinas Pendidikan Kabupaten Kudus.

Wirartha, Made, 2006, Metodologi Penelitian Sosial Ekonomi, Yogyakarta: C.V Andi Offset.

Wibowo, 2009. Manajemen Kinerja. Edisi Kedua. Rajawali Pers. Jakarta.

Surat, __, Keadilan Distributif dan Keadilan Prosedural Dinilai Adil Bagi Sebagian Karyawan, Portal Universitas Gadjah Mada@Universitas Gadjah Mada, Yogyakarta.webugm@ugm.ac.id.

Surat, 2007, Pengukuran Kinerja Non Finansial - 2, Vibiznews - Strategic. http://www.managementfile.com/journal.php?id=37\&sub=j ournalerpage $=$ serviceserawal $=80$

UU Republik Indonesia No.24 Tahun 2007 tentang Penanggulangan Bencana 